Measurements in the flesh of the thirteen individuals obtained were also taken, and are as follows :-

\begin{tabular}{|l|r|r|r|r|r|r|r|r|r|r|r|r|r|}
\hline Supposed age (yrs.)... & 3 & 3 & 5 & 5 & 5 & 5 & 5 & 6 & 6 & 6 & $6 ?$ & 6 & 6 \\
& in. & in. & in. & in. & in. & in. & & in. & in. & in. & in. & in. & in. \\
Extreme length ......... & $65 \frac{1}{2}$ & 63 & 62 & 64 & 64 & 66 & $\ldots$ & 66 & 65 & 66 & 66 & 67 & 67 \\
Greatest girth ......... & 53 & 53 & 56 & 54 & 55 & $\ldots$ & $\ldots$ & $56 \frac{1}{2}$ & $\ldots$ & 54 & 53 & 54 & 55 \\
Height at shoulder ... & 38 & 39 & 38 & $39 \frac{1}{2}$ & 37 & $\ldots$ & $\ldots$ & 40 & 41 & 40 & 37 & $40 \frac{1}{2}$ & 39 \\
\hline
\end{tabular}

The above measurements are in English inches.

The animals seemed to confine themselves to the precipitous slopes of the sea-cliffs, and were in small herds of from three to nine individuals, all of which apparently were males between the ages of three and six years. As in the case of other Wild Sheep, the females and young males doubtless keep apart ; but we were not fortunate enough to discover their habitat, neither could we obtain any information about them from the natives.

I regret to say that the two skeletons we prepared were lost during a typhoon encountered by the 'Marchesa' in the China seas on her return voyage.

\title{
8. On the Geographical Races of the Rocky-Mountain
} Bighorn. By Lieut.-Col. JoHn Biddulph, F.Z.S.

[Received June 16, 1885.]

In the 'Proceedings of the United-States National Museum' for last year, Mr. Nelson has given the name of Ovis montana dalli to the Wild Sheep of Alaska, which he describes as a new geographical race of the Bighorn of the Rocky Mountains. Mr. Nelson relates that he saw two individuals in a wild state, and many hundreds of skins of the species, while he was in Alaska. He states that it inhabits suitable localities all over Alaska and in British North America. Few details of description are given in the paper, but a fuller account is promised in a general list of Alaskan Mammals now in course of preparation. Beyond stating that it is of a uniform dirty-white colour, so that the posterior disk is indistinguishable, and that its horns are smaller, Mr. Nelson points out no differences between specimens of the Alaskan species or variety and specimens from the United States.

Having devoted some time to studying the Wild Sheep both of Asia and America, I had noticed the fact that there are two distinct types to be distinguished among the North-American Wild Sheep before I had seen Mr. Nelson's paper; but I will not at present go so far as to say that they constitute two distinct species. 
The Wild Sheep are so puzzling a group, and slight variations in colour and horn are so common among individuals from the same locality, that it is difficult sometimes to define different species. Specimens from the extreme north of the Rocky Mountains differ, however, so greatly from those procured in the United States, as to deserve future specific distinction, unless specimens from intermediate localities can be found to connect the two.

All naturalists who have studied the Ovine group are aware of the confusion that has been caused in discriminating species, partly through want of accuracy in noting the exact localities whence specimens have been procured, and partly by the impossibility of collecting together for comparison a sufficient number of specimens. It was Mr. Seebohm, I think, who once classified naturalists as "lumpers" and "splitters." The Wild Sheep have suffered severely from both classes. Buffon and Pennant mention the Wild Sheep of Corsica, Sardinia, Tartary, Siberia, Kamtschatka, and California as varieties of the Mouflon. Schreber, under the specific name of AEgoceros argali, lumps up together the North-American, Siberian, and Thibetan Wild Sheep. Even so late as 1871, Blyth, writing to the 'Field' under the name of "Zoophilus," failed to distinguish between the Rocky-Mountain species and the Kamtschatkan species, $\boldsymbol{O}$. nivicola. In the way of splitting, the Rocky-Mountain Bighorn, of which only one species has been recognized, had no less than five specific names given to it between 1803 and 1830 .

That there may be substantial grounds for separating the northern Bighorn from the southern species is shown by the difficulties that have been experienced by the British-Museum authorities in naming the North-American specimens now in their possession.

Among the stuffed specimens exposed to public inspection are two from North America: the one from the Yellowstone River is labelled canadensis, which is the correct specific name of the Rocky-Mountain Sheep, supposing only one species to exist ; and the other, from Liard's River, is labelled nivicola or the Alaskan Wild Sheep, though the true $O$, nivicola is not found in America. In a corner of the same case is a specimen of $O$. nivicola from Kamtschatka without any name on its label. There is also stowed away in one of the basement rooms a stuffed specimen in bad preservation, labelled canadensis. This is the specimen described and figured by Richardson in the 'Fauna Boreali-Americana,' and is identified by Mr. Nelson as belonging to the new variety which he has named after Mr. Dall. It is of the same type or race as the specimen from Liard's River, but is in its summer coat, whilst Dr. Rae's specimen is in its spring or winter coat. Comparison of these specimens will show how those from Alaska and British North America came to be classed as O. nivicola.

In a paper published in the Society's ' Proceedings' for 1875 by Sir V. Brooke and his brother on the large Wild Sheep of Asia, it was pointed out that $O$. nivicola differs from the Bighorn in the shortness of its face and its great proportionate breadth across the orbits. There is another equally noticeable point of distinction in the colour of the hind quarters. 
Both types of the North-American Sheep have a large dirtywhite posterior disk, which is very conspicuous except in the old males in summer, when the whole of the body becomes nearly white; they have also a dorsal stripe, which is more or less conspicuous. In $O$. nivicola there is no disk showing above the tail ${ }^{1}$, though the posteriors are white and the dorsal stripe is wanting. There are other characteristics in which $O$. nivicola differs from the southern race of the Bighorn, but which it shares with the northern race. In all three the horn is smoother, less wrinkled, and more goat-like in character than in other known species of true Wild Sheep; but both $O$. nivicola and the northern race of the Bighorn have the horns less massive, and in both the points turn out abruptly, so that the tips are sharp and seldom broken, and point outwards; while the southern race of Bighorn has the horns massive at the base, the tips blunt, generally broken, and pointing forwards.

The ears in $O$. nivicola are very small and rounded, giving the idea that they have been cut, and are thickly furred to the edges. In the northern race of Bighorn the ears are also small and thickly furred, but have blunt points instead of being rounded. In the southern race of Bighorn the ears are broad, pointed, and deerlike, moderately coated with hair, and are, if anything, rather larger than in any of the known species of Asiatic Argali, measuring in the dried skin fully an inch longer than those of the northern race. Another point of distinction between the two races of Bighorn is in the size of the skull, the southern race having a skull averaging from an inch to an inch and a half longer, and from half an inch to one inch broader than the northern race. There are also considerable apparent differences in colour between the two races of Bighorn; but I have not been able to examine a sufficient number of specimens to be sure how far these differences are constant. I have failed to find any specimens of the southern race with the dark winter coat like the specimen from Liard's River, nor can I find any mention of their ever assuming it. There appear to be also slight differences in the distribution of the colour on the legs. The northern race also has the hair between the ears at the back of the horns growing into a long curly tuft, which also happens in $O$. nivicola, but not in the southern race of Bighorn.

The subjoined table contains some comparative measurements of specimens of the heads of the two races of the Bighorn.

1 This is clearly shown in Eschscholtz's figure of O. nivicola (Zool. Atlas). 


\begin{tabular}{|c|c|c|c|c|c|}
\hline & \multicolumn{3}{|c|}{$\begin{array}{c}\text { BignonN. } \\
\text { Southern Race. }\end{array}$} & \multicolumn{2}{|c|}{$\begin{array}{c}\text { BighonN. } \\
\text { Northern Race. }\end{array}$} \\
\hline & $\begin{array}{r}\text { Stuffe } \\
\text { kill } \\
\text { Wyomi } \\
44^{\circ} 30\end{array}$ & $\begin{array}{l}\text { heads } \\
\mathrm{d} \text { in } \\
\text { g, about } \\
\text { N. lat. }\end{array}$ & 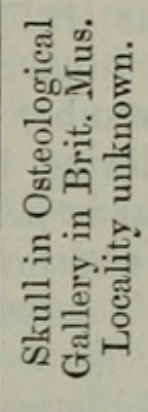 & 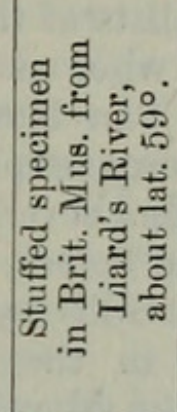 & 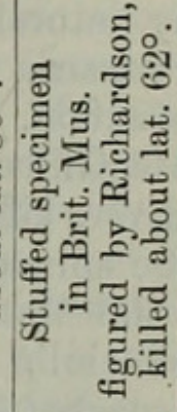 \\
\hline $\begin{array}{l}\text { Length of horn, measured } \\
\text { round fronto-nuchalcurve }\end{array}$ & in. & $\begin{array}{l}\text { in. } \\
33 \cdot 25\end{array}$ & $\begin{array}{l}\text { in. } \\
38 \cdot 25\end{array}$ & $\begin{array}{l}\text { in. } \\
32 \cdot 2\end{array}$ & $\begin{array}{l}\text { in. } \\
32 \cdot 1\end{array}$ \\
\hline Circumference at base ....... & 16 & 16 & $16 \cdot 25$ & $11 \cdot 8$ & 13 \\
\hline $\begin{array}{l}\text { Length of face from supra- } \\
\text { occipital edge to end of } \\
\text { præmaxillaries ............ }\end{array}$ & 12 & 12 & 11.75 & $10 \cdot 5$ & $10 \cdot 6$ \\
\hline Breadth over orbits ......... & 8 & $7 \cdot 5$ & $7 \cdot 25$ & 7 & 7 \\
\hline Apparent age......... & $11 \mathrm{yrs}$. & 11 yrs. & 8 yrs. & 8 yrs. & 7 or $8 \mathrm{yrs}$. \\
\hline
\end{tabular}

The American Bighorns have a wide range. They are found along the whole course of the Rocky Mountains, both on their eastern and western slopes, as far south as Sonora and New Mexico, about lat. $31^{\circ}$ (Schott), and extending to the furthest northern point of suitable ground to lat. $68^{\circ}$ (Audubon). They are also found in the lesser mountain-chains extending from British Columbia to California along the eastern Pacific Coast (Baird), and in Alaska (Dall). It will not therefore be strange if more than one species should be proved to exist. Further evidence is needed to show where the northern race or species has its southernmost limit, and to which the original specific name canadensis was applied. Specimens from the Yellowstone River have somewhat less massive horns than those from Wyoming and Colorado, but in other respects belong to the southern race. Baird also figures the horns of a specimen from California, on the 35 th parallel of latitude, which measure only thirteen inches in circumference at the base, and apparently approximate in character to those of the northern race.

As some confusion exists as to the names already applied to the Bighorn, it may be useful to give an account of the most important references to it. The earliest notice is to be found in the account of California by Father Picolo, one of the first Catholic missionaries who visited that country in 1697 (Abridg. Phil. Trans. London, vol. v. p. 459). He describes it as a sort of Deer. "It is as large as a calf of one or two years old; its head is much like that of a Stag; its horns, which are very large, like those of a Ram; its tail 
and hair are speckled and shorter than a Stag's, but its hoof is large, round, and cleft as an Ox's. Their flesh is very tender and delicious." It is also mentioned by other Spanish writers on California of that period. The species then appears to have been lost sight of by naturalists of the 18th century. The only one to allude to it was Pennant, who, as I have already mentioned, calls it a variety of Mouflon. In November 1800, an adventurous Scotchman, named MacGillivray, exploring in the Rocky Mountains along the Bow River, killed several in lat. $50^{\circ}$. $\mathrm{He}$ had apparently never heard of the animal before, and found little difficulty in shooting them. In 1803 MacGillivray's account was published, with a woodeut, by Dr. Mitchill, in the 'New York Medical Repository.' A specimen procured by MacGillivray was given at the same time to the NewYork Museum. In the same year a description, transcribed from the New-York account, was published in Paris by E. Geoffroy. de St.Hilaire, with a woodcut from a drawing of the New-York specimen. The cut is almost identical with the one published in New York, but is larger. No name beyond that of Bélier de montaigne is assigned to it by Geoffroy.

In or about 1804 an account of the species was published in vol. xv. of Shaw's 'Naturalist's Miscellany,' with a figure and the name of Ovis canadensis. The figure is coloured, but with this exception and the addition of a background it is scarcely to be distinguished from a reversed copy of Geoffroy's figure. Shaw, however, mentions that a specimen is in the British Museum, and makes no allusion to MacGillivray, so that it would appear that he was ignorant of the New-York publication. The exact date of Shaw's publication cannot be verified. There are twenty-four volumes in the series, the first of which was published in 1790, and the last in 1813, but the intermediate volumes are not dated. It is fair to suppose that one volume was published every year, and that the fifteenth was published in 1804 . In 1817 Cuvier mentions it as "probably a kind of Argali that had crossed on the ice from Asia," under the name of Ovis montana, and refers to a figure by Schreber. Schreber's work was not published till 1836, but some of the plates were issued earlier. The work contains two figures of $O$. montana, one of them being a coloured copy of Richardson's figure in the 'Fauna Boreali-Americana,' which was published after Cuvier's work; it is therefore evidently the former figure, which is only a reproduction of Geoffroy's, to which Cuvier refers. It is impossible to say by whom the specific name of montana was first conferred on this Sheep. It is assigned by different writers to Geoffroy, Cuvier, and Desmarest ; but the name appears to have been used by Schreber before either of the two latter, and is assigned by him to Geoffroy. From other references it would appear that the name has been erroneously assigned to Geoffroy, and was probably first employed by Schreber for Geoffroy's figure, the date of Schreber's republication of which is unknown, Geoffroy's name being turned into Latin. In 1818, Desmarest, referring to MacGillivray's account, gave the specific name cervina to the Bighorn. But in his 'Mammalogie,' published two 
years later, he suppressed the name and returned to that of montana, which he also ascribes to Geoffroy, whose figure he again reproduces. In 1827 Hamilton Smith gave the name of pygargus to the RockyMountain Sheep. The accompanying figure is certainly of the southern or heavy-horned species, but he gives no information about the animal. In 1829 Douglas gave the name of californianus to the Wild Sheep that inhabits "the subalpine region of Mount's Wood, St. Helens, and Vancouver, but is more numerous in the mountainous districts in the interior of California." He gives very exact measurements, one of which assigns a length of eighteen inches to the tail; but as he states that he never saw one alive, but founded his species on one good skin seen "about the great falls of the Columbia River," and as no species of Wild Sheep yet identified is known to have a tail approaching to this length, the name cannot stand. In the work on the Natural History of Central America now in course of publication by Messrs. Godman and Salvin, Mr. Alston has restored Desmarest's name of cervina, on the ground that the name of montana, which he assigns to Cuvier, was applied to the Rocky-Mountain Goat before Cuvier wrote. There appears no reason why the same specific name should not be used in both genera; but as Shaw's name of canadensis was published long before Cuvier wrote, and before there is any proof of the name montana having been used by Geoffroy or by Schreber, it must have priority.

The local name of Taye, which is sometimes given to museum specimens, is taken from MacGillivray's original account, and is apparently a misprint for Tajé, which, according to Schott, in the U.S. Mexican Boundary Report, is the name used for the Bighorn by an Indian tribe in California. There appear to be no good reason for retaining so purely local a name. "My-attic" and "Ema-ki-canow" are also mentioned by MacGillivray as Indian names for the Bighorn.

The most important references to the Bighorn are as follows:-

1803. Mountain Ram of North America, Mitchill, New York Repository, p. 237 (fig.).

1803. Bélier de Montaigne, E. Geoffroy de St.-Hilaire, Annales du Musée d'Histoire Naturelle, tom. ii. p. 360 (fig.). (fig.).

1804. Ovis canadensis, Shaw, Naturalist's Miscellany, vol. xv.

1817. O. montana, Cuvier, Règne Animal, tom. i. p. 267.

1818. O. cervina, Desmarest, Nouveau Dictionnaire d'Histoire Naturelle, vol. xxi. p. 553.

1820. O. montana, Desmarest, Mammalogie, p. 487 (fig.).

1827. O. pygargus, Hamilton Smith, Cuvier's Animal Kingdom (fig.). 332 .

1829. O. californianus, Douglas, Zoological Journal, vol. iv. p.

1829. O. montana, Richardson, Fauna Boreali-Americana (fig.).

1836. Der Amerikanische Argali, Schreber, Die Säugthiere, vol.v. p. 1367 (2 figs.). 
1840. O. montana, Blyth, Proc. Zool. Soc. 1840, p. 77.

1840. O. californiana, Blyth, ibid.

185̃1. O. montana, Audubon and Bachman (fig.).

1854. O. montana, Richardson, Voyage of H.M.S. 'Herald' (osteological fig.).

1857. O. montana, Baird, Mammals N. America, Survey Reports, p. 673 (fig. of horn).

1859. O. montana, Schott, U. S. Mexican Boundary Report, part ii. p. 52.

1871. O. canadensis, Blyth ("Zoophilus"), The Field, May 13

1880. O. cervina, Alston, Biologia Centr.-Am., Mammal. p. 111.

1884. O. montana dalli, Nelson, Proceedings of U.S. National Museum, vol. vii. p. 13.

9. On the Avian Sternum.

By Beatrice Lindsay, Girton College, Cambridge ${ }^{1}$.

[Received June 16, 1885.]

$$
\text { (Plates XLII.-XLV.) }
$$

Introduction.

The most typical and simple form of the sternum is that found in Reptiles, where this bone, although associated with a shouldergirdle of maximum complexity, and strengthened by the apposition of an interclavicle in the median line, is itself undoubtedly of homogeneous origin, that is to say derived solely from the fusion of ribs. In Birds and Mammals the sternum has been supposed by some authorities to be, on the contrary, a composite structure, containing a supplementary median element more or less distantly derived from membrane-bone, and homologous with the free $\mathrm{T}$-shaped interclavicle of Reptiles. Much has been done to increase the plausibility of that theory by a vague use of the terms " interclavicle" and "episternum." These names, when first introduced, expressed nothing but a certain anatomical position of the parts to which they were applied; but now that the aforenamed reptilian structure is held by nearly all anatomists to be a membrane-bone, the names given to it inevitably tend to suggest a meaning restricted to particular homologies. But, unfortunately, many authors still apply the said names indiscriminately to any anterior median ossification, or paired ossification approaching the median line, without regard to its origin, whether known or unknown; and thus they unintentionally create factitious evidence for the above-named theory, by the continual implication of homologies which have never been satisfactorily proved. Instances in point are afforded by certain

\footnotetext{
1 Communicated by Dr. H. Gadow, C.M.Z.S.
} 


\section{$2 \mathrm{BHL}$ Biodiversity Heritage Library}

Biddulph, J. 1885. "On the Geographical Races of the Rocky-Mountain Bighorn." Proceedings of the Zoological Society of London 1885, 678-684. https://doi.org/10.1111/j.1469-7998.1885.tb07874.x.

View This Item Online: $\underline{\text { https://www.biodiversitylibrary.org/item/97225 }}$

DOI: https://doi.org/10.1111/j.1469-7998.1885.tb07874.x

Permalink: https://www.biodiversitylibrary.org/partpdf/73111

\section{Holding Institution}

Natural History Museum Library, London

\section{Sponsored by}

Natural History Museum Library, London

\section{Copyright \& Reuse}

Copyright Status: Public domain. The BHL considers that this work is no longer under copyright protection.

This document was created from content at the Biodiversity Heritage Library, the world's largest open access digital library for biodiversity literature and archives. Visit BHL at https://www.biodiversitylibrary.org. 